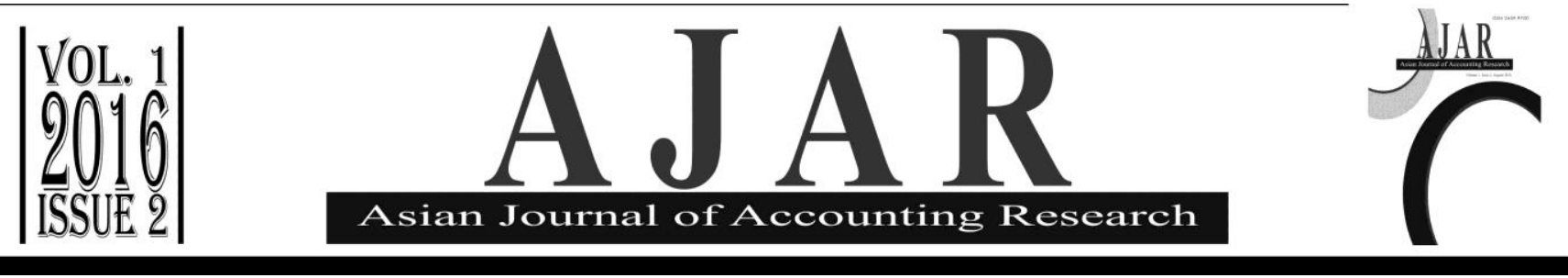

\title{
Determinants Distribution of Financing and the Implications to Profitability: Empirical Study on Cooperative Sharia Baitul Maal wa Tamwil (BMT) in Indonesia Oyong Lisa ${ }^{1}$
}

\author{
${ }^{1}$ STIE Widya Gama Lumajang
}

ARTICLE INFO

Article history:

Received 1 April 2016

Accepted 16 May 2016

Available online 31 August 2016

Keywords:

Capital Structure

Third Party Funds

Non Performing Financing

Distribution Finance

Profitability

\begin{abstract}
A B STR A C T
Financing is one of the main activities and a major source of revenue for Islamic Cooperatives. This study aimed to analyze the effect of capital structure, third party funds and non-performing financing to the finance portfolio as well as to analyze the effect of capital structure, deposits, nonperforming financing and the distribution of funding to profitability. The analysis technique used is multiple regression analysis, using $F$ test and $t$ test. The results of the analysis showed that the capital structure, third party funds and non-performing financing significantly effect on the distribution of funding. Capital structure, third party funds, and the distribution of funding has a significant effect on profitability, Sharia Cooperative BMT in Indonesia. While non-performing financing does not affect the profitability of Islamic Cooperative Baitul Maal Tamwil in Indonesia.
\end{abstract}

\section{Introduction}

Cooperatives are an important part of economy, one of them is as an intermediary whose job collecting funds from the public, and in the form of finance Distribution of funding allows people to make investments, distribution, and consumption of goods and services considering these all investment activities, distribution, and consumption is always associated with the use of money. Community economic development activities comprise smooth operation of the investment, distribution, and consumption. Financing the activities of banks is generating a profit, but the greatest risk in the cooperative is also derived from the distribution of funding. One of the efforts undertaken by the company is strengthening the capital structure of appropriate profit, at least to cover the costs of the company's operations in order to maintain the company. The capital structure of a company illustrates the balance between equity and long-term debt. Thus, companies should always pay attention to proper capital structure in a good order. This is aimed to minimize cost of capital. The selection of alternative funding either from its own capital and foreign capital will greatly affect the amount of profitability obtained by the company. The greater profitability means the greater the company's ability to generate profits for the owners of capital. Relating to the company's capital structure, Berenguer-Contri et al. (2011) reports that there is a positive relationship between short-term debt, long-term debt and total debt to profitability.

In a cooperative operational activities, capital is an important factor in channeling funding to the member. Cooperative capital can also be used to maintain the possibility of risks, including risks arising from the financing itself. To cope with possible risks that occur, a cooperative must provide a minimum capital adequacy. With a substantial capital. A cooperative can channel more financing, in line with the increased financing this will improve the distribution of funding to members. One of the business activities of Islamic Cooperation is to finance the collection and distribution. Fund raising activities derived from the cooperative itself, of the depositor/members, financing from the bank or to a third party, and from other sources. Meanwhile, the distribution of financing activities can be done in various forms, such as the finance portfolio, investment activities, and in the form of fixed assets and inventory. Cooperative fund raising activities are largely sourced from the savings of their members in the form of demand deposits, savings and time deposits. Member savings is often referred to as the Third Party Fund (TPF). TPF is mostly distributed in the form of financing. Haron (1995) conducted a study of some factors that affect profitability in some Islamic banks in the world, proving that there are two factors affecting the profitability of Islamic: namely internal and external variables. Internal factors such as liquidity, capital structure, and the structure of deposits and financing structures affect the profitability of 
Islamic banks. While external variables include market share, money supply, interest rates, inflation and the size of the bank. Financing has been distributed by the cooperative to the public to have a potential emergence of non-performing loans. Non-performing loans can be seen in the level of non-performing financing (NPF). If the level of NPF /high non-performing loans, the profitability will decline, while if the level is low, the NPF's profitability will increase. Hadiyati and Baskara (2013) proved that NPF had a significant effect on profitability. This study aimed to analyze the effect of capital structure, third party funds and non-performing financing to the finance portfolio as well as to analyze the effect of capital structure, third party funds, non performing financing and the distribution of funding to profitability.

\section{Literature Review}

\subsection{Profitability}

Profitability is the company's ability to obtain profits in relation to sales, total assets and own capital (Sugiyarso and Winarni, 2005). Thus long-term investors will be concerned with profitability analysis, for example the shareholders will see the benefits in the form of dividends. Sartono (2011) defines profitability as: "the ability of the company to make a profit in relation to sales, total assets, or equity". Profitability analysis is an analysis of company ability in its own capital and assets for generating profits. With profitability analysis, can identify the cause of profit or loss. Profitability in this study employs a return on equity (ROE) compared to gross profit margin, net profit margin, profit margin and return on assets because ROE is a ratio which is very important for the owner of the company, as this ratio indicates the level of return generated by the management of capital provided by the owner of the company. In other words, ROE shows the benefits gained by shareholders. ROE shows better growth prospects of the company, which means the potential for increased corporate profits. Research conducted by Haron (1995) suggest that the factors affecting the profitability of Islamic banks are divided into two categories, namely internal and external variables. Internal factors such as liquidity, capital structure, and the structure of deposits and financing structures affect the profitability of Islamic banks.

\subsection{Distribution of Funding}

Muhammad (2005) stated that a "financing is provided by one party to another to support the planned investment, either by themselves or the institution." It is important to understand the financing based on Law No. 21 of 2008 concerning Banking article 1 (12): "Financing based on Islamic principles is the provision of money or bills that may be equivalent based on agreements between the Bank and another party requiring the financed party to return the money or bills after a certain period in exchange or for the results". Thus financing is provided by one party to another or the agreement between the bank and the customer to support the planned investment, either by themselves or the institution.

According to Kasmir (2008), "financing is the provision of cash or equivalent which is based on interbank or agreement with another party requiring the financed party to return the money or the bill after a certain period in exchange or for the results". According to Muhammad (2005), finance broadly means financing or expenditure, called funding which is issued to support the planned investment, either by themselves or run by someone else. In a narrow sense, the financing is used to determine funding conducted by financial institutions, such as Islamic banks, to the members ".

\subsection{Capital Structure}

Capital structure with regard to multiple sources of capital can be obtained by the company to finance its operations, the company needs to establish which one to be the choice of the use of capital, in order to create a composition of the capital structure which will benefit the company. According Sudana (2011), "Capital Structure is related to a company's long-term spending as measured by the ratio of long-term debt with its own capital." Brealey et al. (2007), mention that "capital structure is a mix of long-term debt financing and equity financing", whereas Sartono (2011) states that "capital structure is balancing the amount of short-term debt that is permanent, long-term debt, preferred stock, and common stock. In fact, financial structure is the balance between total debts with its own capital. In other words, the capital structure is part of the financial structure."

\subsection{Third-Party Funds}

Third party funds needs a Sharia Cooperative in running its operations. Dendawijaya (2009) defines thirdparty funds in the form of deposits from the public. This turns out to be the largest funding source of the most reliable banks (reaching $80 \%-90 \%$ of all funds managed by the bank). Banks may utilize funds from the third party to place some items that generate income for the bank, one of which is in the form of financing. The growth of third party funds will cause the financing of growth, which in turn loan to deposit ratio will also increase. Communities that surplus funds can save their money in banks in the form of savings, deposits, current accounts, certificates of deposit. According to Bank Indonesia Circular Letter No. 6/23/DPNP dated May 
31,2004 , the public funds are entrusted to the bank or funds from third parties and collected by the banking sector are as follows:

a. Savings deposits are deposits that may be only withdrawn under certain conditions, but it cannot be withdrawn by check, giro. Savings accounts are usually owned by people with business activities which are relatively small, even non-existent.

b. Time deposits are deposits that can be withdrawn only at a specific time based on the agreement with the depositary of bank members. Funds from the most expensive deposits are those which must be issue by the bank. Funds from time deposits are generally collected from medium entrepreneurs and people from the upper middle class that is not a business partner.

c. Demand deposit is a deposit which may be withdrawn at any time by cheque, demand deposit, government facilities other payment, or to transfer items. Current accounts is commonly used by businessmen with high liquidity so that the movement of funds can be very quickly. Having a checking account for entrepreneurs is an absolute necessity for smooth business and affairs of the payment.

d. Certificate of deposit is a deposit in the form of a certificate which has transferable evidence storage.

The more funds owned by a cooperative, the greater the opportunity for the cooperative to undertake its activities to achieve goals. Taswan (2008) explains that the growing number of third-party as a major of funding source makes a bank put these funds in the form of, for example financing of productive assets. This financial form can contribute to the bank's interest income that would have an impact on the bank's profitability (profit). Maulida (2010) reported that the amount of third party funds affect profitability growth.

\subsection{Non Performing Financing}

Dendawijaya (2005) defines Non-Performing Finance (NPF) is "the failure of a debtor to meet his obligations to pay installments loan which has been agreed." Wangsawidjaja (2012) argues that: "The higher non-performing Finance (NPF) is, the lower profit that a company gain due to this profit is in small enterprises ". According to Mahmoeddin (2004), Non Performing Finance is basically caused by internal and external factors. External Factors is a Factor of debtors showing that not all of them have a good faith when applying for a loan or when a loan is granted under way. This kind of faith it is indeed difficult to be identified and analyzed by the bank, because it concerns with morals or morality of the debtor. It could be the debtor when applying for a loan to cover up its financial wrack and only expect fresh funds from the bank, or the debtor is providing false financial data or a variety of other actions. The second one, linternal Factors shows that faith is not coming from the owners. Their executives and employees of the bank are often providing credit to borrowers. Business activities do not include activities which have less obvious goals. Less obvious debtors (or can be called fictitious debtor) are those who report the actual use of funds which are different from that stated at the evidence there.

\subsection{Hypothesis}

$\mathrm{H}_{1} \quad$ : Capital structure has a significant influenceto the distribution of funding.

$\mathrm{H}_{2}$ : Third party funds have a significant influenceto the distribution of funding.

$\mathrm{H}_{3}$ : Non Performing Finance has a significant effect onthe distribution of funding.

$\mathrm{H}_{4}$ : Capital structure has a significant influence toprofitability.

$\mathrm{H}_{5}$ : Third party funds has a significant effecton profitability.

$\mathrm{H}_{6}$ : Non Performing Finance has a significant effect on profitability.

$\mathrm{H}_{7}$ : Distribution of funding has a significant effect on profitability.

\section{Research Method}

\subsection{Research Design}

This research employs the design of causality. According to Sanusi (2014) design causality is a research design prepared to examine the possibility of a causal relationship between the variables. In this design, generally a causal relationship (that) could be predicted by the researchers, so that they can declare a variable classification of causes, among variables and the dependent variable (dependent).

\subsection{Population and Sample}

The population in this study is a cooperative Sharia BMT in Indonesia with a total of 98 institutions. Sampling was done by using non fingers and purposive sampling method that is some routine criteria to make full financial report in the period 2012-2013. Based on these criteria, the number of samples in this study were 44 cooperative sharia. 


\subsection{Definition Operational Variable}

1. Profitability

Profitability is one of the financial ratios which measures a company's ability to obtain profit in relation to sales, total assets, and own capital. Profitability is measured by:

Return On Equity $(\mathrm{ROE})=\frac{\text { Net profit }}{\text { Totalcapital }} \times 100 \%$

2. Distribution of Funding

Distribution of funding is the amount of financing issued by the Cooperative Sharia in Rupiah.

3. Capital Structure

Combinations (proportion) of the company's permanent long-term expenditure which are represented by debt, preferred stock to common stock. Measured by the capital structure:

Capital structure $=\frac{\text { Long- termdebt }}{\text { Owner's Equity }}$

4. Third Party Funds

Third party funds is the most important source of funds for the operations of the bank and it measures thesuccess if the bank is able to finance its operations from other sources such as current accounts, savings and time deposits in rupiah.

5. Non Performing Financing

Financing risks are resulting from non-payment. This is not re-financing provided by the Cooperative of Sharia to the debtor.

The formulaof Non Performing Financing(NPF) as follows:

$N P F=\frac{\text { Financing problems }}{\text { Total financing extended }} \times 100$

\subsection{Model Research}

Figure 1 shows the research model using multiple regression analysis.

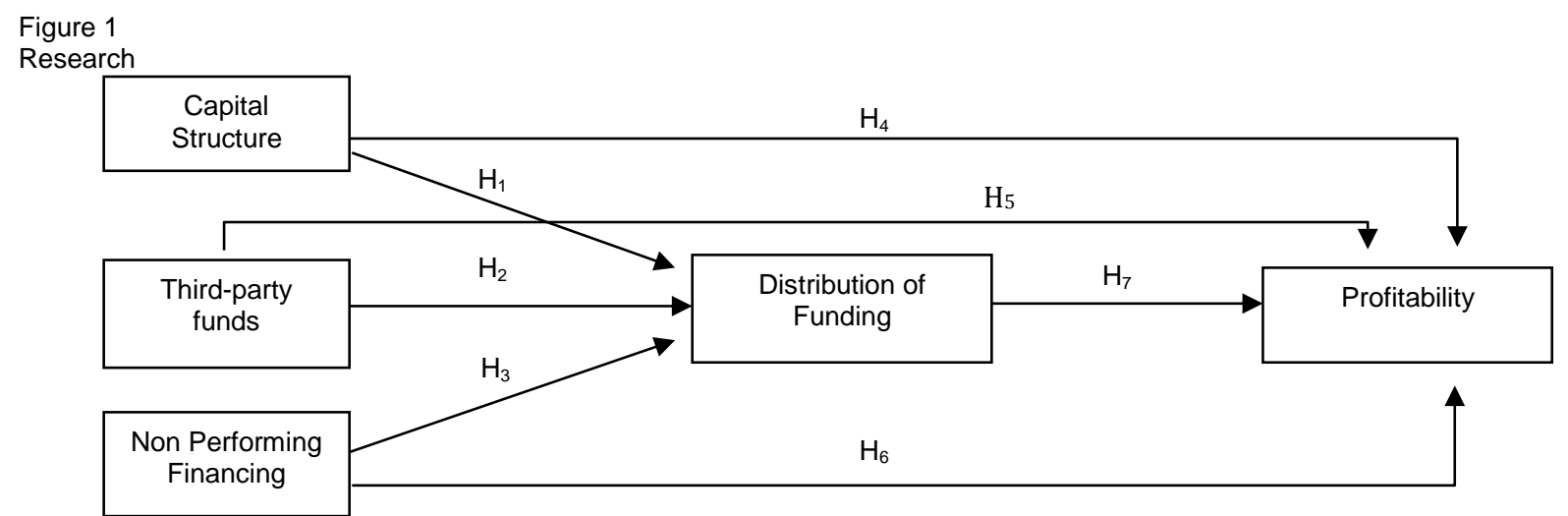

The model in this study consists of two statistical equations as follows.

Distribution of Funding $=a+$ CS1b1 +TPF2b2 + NPF3b3 $+e$

Profitability $=a+$ CS4b4 + TPF5b5 + NPF6b6 + DF7b7 +e

\section{Result and Discussion}

\subsection{Effect of Capital Structure, Third Party Fund and Non Performing Financing to Distribution of Financing}

The results of the analysis of the effect of capital structure, deposits and NPF to the distribution of funding are presented in the following table. 
Table 1

Regression Analysis Effect of capital structure, third party funds and NPF on the Distribution of Funding

\begin{tabular}{lccc}
\hline \multicolumn{1}{c}{ Variable } & Standardized Coefficients Beta & t value & $\mathrm{p}$-value \\
\hline Capital Structure & $-0,112$ & $-2,099$ & $0,039^{\star}$ \\
Third Party Fund & 0,865 & 16,532 & $0,000^{\star}$ \\
NPF & $-0,106$ & $-1,998$ & $0,049^{\star}$ \\
\hline
\end{tabular}

${ }^{*}$ ) Statistically significant at level $\alpha=5 \%$

Table 1 indicates that the influence of capital structure to the distribution of funding is significant, with the regression coefficient $t$ value of -0.112 and -2.099 , and $p$ value of 0.039 . It means that capital structure has significantly influenced the distribution of funding, which means an increase in the capital structure will be followed by a decrease in the distribution of funding.

The influence of third party funds for the distribution of funding is significant at the level of $\alpha=5 \%$, with a regression coefficient of 0.865 and $t$ value of 16.532 and a $p$-value of 0.000 . It means that third-party funds have significantly influenced the distribution of funding, which means an increase in third party funds will be followed by an increase in the distribution of funding.

NPF influence on the distribution of funding is significant at the level of $\alpha=5 \%$, with a regression coefficient of -0.106 and $t$ value of -1.998 and $p$ value of 0.049 . This suggests thatNPF has a significant effect on the distribution of funding, which means an increase in the NPF will be followed by a decrease in the distribution of funding.

\subsection{Effect of Capital Structure, Third Party Funds, NPF and Distribution Financing to Profitability}

The results of the analysis of the effect of capital structure, third party funds, the NPF and the distribution of funding to profitability are presented in the following table.

Table 2

Regression Analysis Effect of Capital Structure, Third Party Fund, NPF and Distribution Financing To Profitability

\begin{tabular}{lccc}
\hline Variable & Standardized Coefficients Beta & t value & $p$-value \\
\hline Capital Structure & $-0,873$ & $-14,096$ & $0,000^{*}$ \\
Third Party Fund & 0,376 & 3,077 & $0,003^{*}$ \\
NPF & $-0,012$ & $-0,197$ & 0,844 \\
Distribution Financing & 0,371 & 3,003 & $0,004^{*}$ \\
\hline
\end{tabular}

$\left.{ }^{*}\right)$ Statistically significant at level $\alpha=5 \%$

Based on Table 2, the effect of capital structure to profitability has asignificant regression coefficient and $t$ value of $-0.873-14.096$ and a p-value of 0.000 . It indicatesthat capital structure has significantly influenced profitability, which means an increase in the capital structure will be followed by an increase in profitability.

The influence of third-party funds to profitability is at a significant level of $\alpha=5 \%$, with a regression coefficient of 0.376 and $t$ value of 3.007 and $p$-value of 0.003 . It demonstratesthat third-party funds has a significant effect on profitability, which means an increase in third party funds will be followed by an increase in profitability.

NPF does not affect the profitability of the regression with the coefficient $t$ value of -0.012 and -0.197 , and a $\mathrm{p}$-value of 0.844 . The size of the company does not affect the profitability, which means an increase in the size of the company does not have an impact on the decrease in profitability.

The influence of the finance portfolio on profitability is at a significant level of $\alpha=5 \%$, with a regression coefficient of 0.371 and $t$ value of 3.003 and $p$-value of 0.004 . That level is significant to the profitability of the finance portfolio, which means an increase in the distribution of funding will be followed by an increase in profitability.

Based onTable1and tabel2, the model ofthis study are presentedin the following figure.

Figure 2

Results of Research Model

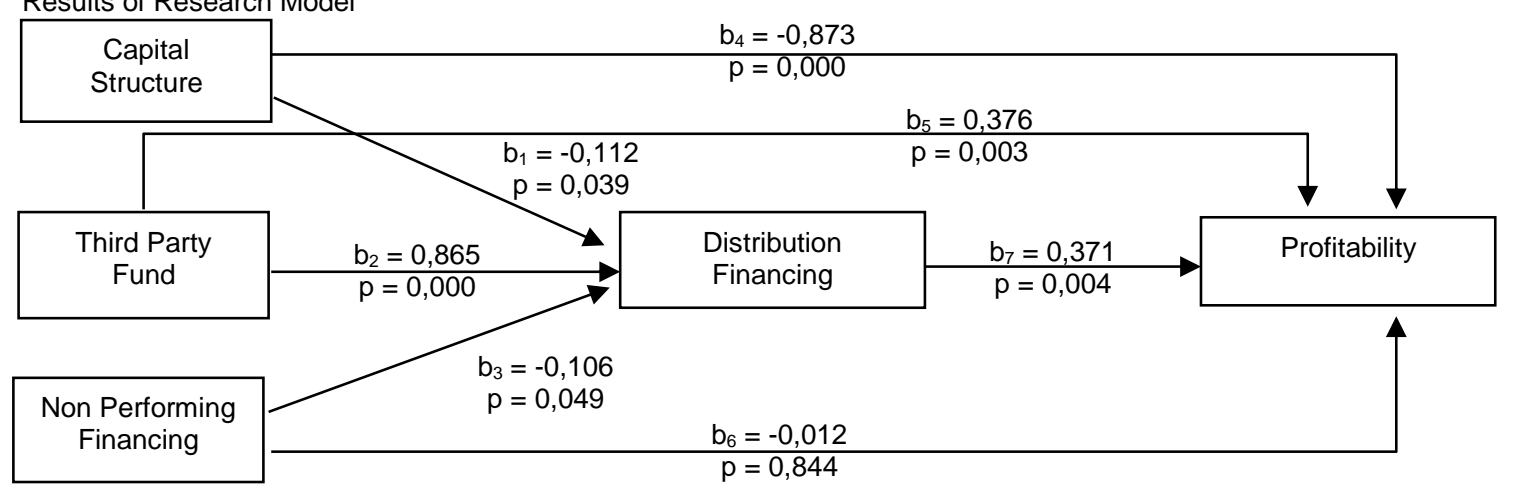




\subsection{Effect of Capital Structure of Distribution of Funding}

Capital structure has significantly influenced on the distribution of funding, which means that the source of funds is the most important thing for the cooperative to increase the amount of financing that will be distributed to the public. The more funds that are owned by the cooperative, the greater chances of cooperatives to carry out its functions. The source of funds may come from the cooperative itself, the funds coming from other institutions, and funds from the public. Funds sourced from public or third party funds (TPF) is an important source of funding for operational activities and is a measure of the success of the sharia cooperative if it is able to finance its operations from this funding source (Kasmir, 2008). These funds maycome from savings, current accounts and deposits. Dendawijaya (2009) revealed that third-party funds raised from the public is the largest and the most reliable funding for banks ( $80 \%-90 \%$ of all funds managed by the bank).

The capital structure has a movement in the direction of profitability. When it is low, the value of the debt would lower the value of its profitability, but if the value of debt is high, it will increase profitability. This view is contradicted to the opinion of Stein (2012) who states that a company which has a rate of return on investment (profitability) tends to have small amount of debt due to the use of their own capital is greater. This notion supports the theory of MM which believes that the use of high debt will increase the value of the company so that the capital structure has a positive effect on firm value. Capital structure can improve the profitability of the company and show the company's financial performance either. This can provide an advantage for the company as it can attract and increase the confidence of investors to continue investing in the company.

\subsection{Effect of Third Party Funds Against Distribution of Funding}

Third party funds have a positive and significant impact on the distribution of funding. This means that the more third-party funds which can be collected by Cooperative Sharia, the more financing disbursed which should be paid out. This is in line with the opinion of Siamat (2005) who argues that one reason for banking business in distributing its funding is the nature of business of banks as intermediary between the unit surplus and with the unit deficit and the main source of funds providers to the community. Therefore, morally they should be channeled back to the community in the form of financing. The funds raised from the public (third party funds) is the largest funding source of the most reliable banks (Dendawijaya, 2009). Activities of the bank after collecting funds from the public are focusing on the people who need it, in the form of loans or the so called financing (Kasmir, 2008). The results of this study are consistent with Maharani (2011) and Murdiyanto (2012) who found that the TPF has effected on the distribution of the amount of financing. This indicates that an increase or decrease in deposits during the study period has significantly affected the distribution of funding. Therefore, the larger the Third Party Funds received, also the increasing role of cooperatives sharia in channeling funds is to shape the distribution of funding. The funds were obtained from the deposit-payment made by the members of the Islamic Cooperation. After getting an injection from, one of the third party, the Cooperative Sharia can distribute these funds to the public, but the proportion is between the amounts of funds allocated to the third party financing.

\subsection{Effect of NPF Against Distribution Financing}

NPF has a negative and significant effect on the distribution of funding, which means that the lower the NPF is, the greater the amount of financing which is provided. Therefore, Sharia Cooperative should the Islamic Cooperation to analyze the debtor's ability to pay back the financing prior to the distribution of funding to the debtor. The smoothness of the debtor in paying its obligations is a must. Financing payment is a necessity fora debtor to run the operations of Islamic cooperatives smoothly. If a Sharia Cooperative has much arrears payment by a debtor, the financing of Islamic cooperative cannot return the capital that has been issued, so it will affect the reputation of Islamic Cooperation, which can decrease the level of public trust. After the distribution of funding has been granted, Sharia Cooperative shall monitor the financing and the ability of users as well as the compliance of the debtor to meet its obligations. Monitoring is conducted in order to minimize credit risk that might occur. If the number of NPF is too high, Sharia Cooperative should provide greater reserves so that capital can be eroded. In fact, the amount of capital greatly influences the magnitude of the funding distribution expansion. Large amount of NPF in Sharia Cooperative makes it difficult to channel funding to the community.

\subsection{Effect of Capital Structure to Profitability}

Capital structure has a significant effect on profitability. It is a combination of debt and equity in the company's long-term financial structure. The right combination of debt and equity is expected to improve profitability. The results of this study imply that the increase and decrease of making long-term debt in the 
capital structure of the company can influence the direction of the net profit value. An increase in the size of the debt will affect profits of the company, reflecting the company's ability to meet all obligations. These findings are supported by Soliha and Taswan (2002) who reported that the higher the proportion of the debt, the higher the value of the company as seen from the profits earned. However, at some point the increase in debt would lower the value of a company. This is because the company's benefit which is obtained from debt is smaller than the cost inflicted. The owner of a company may be able to use a relatively large debt to limit the manager. High debt ratio would increase the threat of bankruptcy, a company thus should be more careful and not to squander the money of shareholders. Most takeovers and purchases through debt are designed to improve efficiency by reducing free cash flow available for managers (Brigham \& Houston, 2006). Expenditure carried out by financial management will create a financial structure which shows the ratio of funding sources used to finance the company operation. For each company, the decision in determining the source of funding is important because it will affect the company's financial structure, which ultimately will affect profitability. Research conducted by Dickins and Houmes (2009) found that the investment strategy based on capital ownership of the company (equity) was positively related to the profitability. This means if a company obtains greater results from borrowed funds rather than from the paid one as interest, then the returns in the form of profit for the owners will increase.

\subsection{The Effect of Third Party Funds to Profitability}

Third party funds have a significant effect on profitability. This suggests that sharia cooperative activities are channeled back the funds to people in need after collecting funds from the public in the form of demand deposits, savings and time deposits. The allocation of funds can be realized in the form of financing. The provision of financing is a cooperative activity in generating profits. Third party funds (TPF) is one of the largest sources of funds obtained from the community. Cooperative sharia can utilize funds from the third party that is for items that generate income for the cooperative, one of which is in the form of financing. The increase of funds in third party will lead to greater growth in financing which can increase the profitability of the cooperative. Regarding this situation, Taswan (2008) pointed out that with the growing number of third-party funds as a major source of funding, banks can put these funds in the form of, for example, financing of productive assets. Placement in the form of financing will contribute to the bank's interest income which could bring an impact on profitability of bank. The results of this study are consistent with the research conducted by Maulida (2010) which proved that the amount of third party funds affected the profitability growth.

\subsection{The Effect of NPF to Profitability}

NPF does not affect the profitability, thus when NPFs increases, profitability will not be affected by the increase and NPF cannot be used to predict profitability. This can happen because of malignant neglect of the debtor or any other problems that are beyond the control of the debtor. If NPF shows a very high increase, the health level of Islamic cooperatives will decrease the value of the owned assets. Sharia Cooperative must always keep the finance portfolio from entering the troubled financing (NPF). The results of this study are inconsistent with Hadiyati and Baskara (2013) which states that NPF has a significant effect on profitability. Therefore, the provision of financing is important to make profits. A financial institution will provide financing to their customers and they need to make sure that the customers will receive the financing and have a willingness to restore the funding that has been received. Some factors such as capabilities show that profits or profitability is the purpose of the provision in financing which embodied in the form of profit margins/received profits, and security/safety, which is often called safety of achievement or provided facilities which absolutely guarantee the returns, so that the purpose of profitability can be really achieved without any significant obstacles.

\subsection{The Influence of Distribution of Financing to Profitability}

Distribution of funding has a significant effect on profitability. This suggests that the distribution of funding is the activity of Islamic cooperatives in generating profits. Muhammad (2005) reveals that the purpose of financing is after the third-party funds collected by the bank should be in accordance with the intermediary functions, then the bank is obliged to distribute these funds to financing. In this case bank should prepare a funding strategy which is in accordance with the plan allocation stated in the policy. The allocation aims to achieve sufficient levels of profitability and low level of risk, and to maintain public trust and keep the liquidity position to remain secure. Micro financing objectives are set out to achieve the maximum profits this indicates that every business has an ultimate goal to gain its operating income. Every business aims to achieve maximum profit in which they can make by the support of sufficient funds.

\section{Conclusion}

Capital structure, deposits and NPF have a significant effect on the distribution of cost. Capital structure, funding and distribution of third party financing have a significant effect on profitability. This shows that the amount of credit distribution is determined by the amount of the capital structure, third party funds and NPF, 
therefore Sharia Cooperative needs to set a specific target concerning the amount of debt to equity. The greater the Third Party Funds which is received, it will increase the role of Sharia Cooperative in channeling funds to those who lack of funds. This funding distribution has an impact on increased profitability. NPF has no effect on profitability, therefore, in order to increase profitability, the Sharia Cooperative should have a strategy in order to boost the increase of NPF by being more selective in assessing its potential borrowers who will receive financing, and improving competent human resources in the provision of financing to customers. By doing that, NPF can be minimized, and monitoring can be routinely performed to clients in order to narrow the gap deviation of the financing use. Distribution of funding needs to be maintained for Sharia Cooperative in order to obtain a return that is able to cover the loss of financing problems, and if the Sharia Cooperative intends to use long-term debt as an external funding source, the cooperative should consider the structure of its assets especially when the amount of fixed assets can guarantee the debt. Cooperatives should maintain high profitability because they can finance most of theire needs with retained earnings, which may reduce the dependence on external finance in business activities. To achieve and maintain high profitability, the cooperative must manage its resources (total assets) efficiently and to optimize collected funds in order to increase profit/loss as well as to maintain the balance of the public funds and to prevent the deposition of funds so that profitability will increase.

\section{References}

Bank Indonesia. 2004. Surat Edaran Bank Indonesia No. 6/23/DPNP tentang Sistem Penilaian Tingkat Kesehatan Bank Umum. Jakarta: Bank Indonesia.

Berenguer-Contri, G., Ruiz-Molina, M., Gil-Saura, I., 2011. Relationship Benefits and Costs in Retailing : A Cross-Industry Comparison. Journal of Retail and Leisure Property 8 (1), 57-66. DOI: 10.1057/rlp.2008.27.

Brealey, R. A., Myers, S. C., Marcus, A. J., 2007. Basics of Financial Management. Jakarta: Erlangga.

Brigham, E. F., and Houston, J. F., 2006. Financial Management Book II. Jakarta: Erlangga.

Dendawijaya, L., 2005. Manajemen Perbankan. Jakarta: Ghalia Indonesia. 2009. Manajemen Perbankan. Jakarta: Ghalia Indonesia.

Dickins, D., and Houmes, R., 2009. Revisiting the Relationship between Insider Ownership and Perfomance. Journal of Business and Economic Studies 15 (2), 32-43.

Hadiyati, P., and Baskara, R. A., 2013. Pengaruh Non Performing Financing Pembiayaan Mudharabah dan Musyarakah pada Bank Muamalat Indonesia. e-Journals Manajemen dan Bisnis 1 (1), 1-14.

Haron, S., 1995. The Frame Work and Concept of Islamic Interest-Free Banking. Journal of Asian Bussines 11 (1), 26-39.

Indonesia, 2008. Undang-Undang Republik Indonesia Nomor 21 Tahun 2008 tentang Perbankan Syariah.

Kasmir, 2008. Bank dan Lembaga Keuangan Lainnya. Jakarta: RajaGrafindo Persada.

Maharani, A., 2011. Analisis Faktor-Faktor yang Mempengaruhi Penyaluran Jumlah Kredit PT Bank Tabungan Negara (Persero), Tbk. Cabang Makassar. Undergraduate Thesis. Universitas Hasanuddin Makassar.

Mahmoeddin, 2004. Melacak Kredit Bermasalah. Jakarta: Pustaka Sinar Harapan.

Maulida, I., 2010. Pengaruh Indikator Keuangan dan Non Keuangan terhadap Pertumbuhan Profitabilitas Bank Perkreditan Rakyat di Indonesia. Master Thesis. Universitas Syiah Kuala.

Muhammad, 2005. Manajemen Bank Syariah. Yogyakarta: UPP AMP YKPN.

Murdiyanto, A., 2012. Influential Factors In Determining Lending Banking Study on Commercial Banking Indonesia Period 2006-2011. Proceedings of Conference In Business, Accounting and Management (CBAM). Vol. 1 No. 1: 61-75.

Sanusi, A., 2014. Metodologi Penelitian Bisnis. Jakarta: Salemba Empat.

Sartono, A., 2011. Manajemen Keuangan (Teori dan Penerapan). Yogyakarta: BPFE.

Siamat, D., 2005. Manajemen Lembaga Keuangan. Jakarta: Lembaga Penerbit FEUI.

Soliha, E., dan Taswan, 2002. Pengaruh Kebijakan Hutang terhdap Nilai Perusahaan serta Beberapa Faktor yang Mempengaruhinya. Jurnal Bisnis dan Ekonomi.

Stein, E. T., 2012. Pengaruh Struktur Modal (Debt Equity Ratio) terhadap Profitabilitas (Return On Equity): Studi Komparatif pada Perusahaan Industri Tekstil dan Garment yang Terdaftar di BEI Periode 2006-2010. Undergraduate Thesis. Universitas Hasanuddin Makassar.

Sudana, I. M., 2011. Manajemen Keuangan Perusahaan (Teori and Praktik). Jakarta: Erlangga.

Sugiyarso, G. and Winarni, F., 2005. Manajemen Keuangan: Pemahaman Laporan Keuangan Pengelolaan Aktiva, Kewajiban dan Modal, serta Pengukuran Kinerja Perusahaan. Yogyakarta: Media Pressindo.

Taswan, 2008. Manajemen Perbankan: Konsep, Teknik \& Aplikasi. Yogyakarta: UPP STIM YKPN.

Wangsawidjaja, A. Z., 2012. Pembiayaan Bank Syariah. Jakarta: PT. Gramedia Pustaka Utama. 